\title{
Effect of Partial Fat Replacement by Whey Protein, Oat, Wheat Germ and Modified Starch on Sensory Properties, Viscosity and Antioxidant Activity of Reduced Fat Ice Cream
}

\author{
Samir A. Salem1, Essam M. Hamad1,2, Ihab S. Ashoush',3 \\ ${ }^{1}$ Food Science and Human Nutrition Department, College of Agriculture and Veterinary Medicine, \\ Qassim University, Qassim, Saudi Arabia \\ ${ }^{2}$ Dairy Science Department, Faculty of Agriculture, Cairo University, Giza, Egypt \\ ${ }^{3}$ Department of Food Science, Faculty of Agriculture, Ain Shams University, Cairo, Egypt \\ Email: ihab.ashoush@gmail.com
}

Received 28 March 2016; accepted 6 May 2016; published 9 May 2016

Copyright (C) 2016 by authors and Scientific Research Publishing Inc.

This work is licensed under the Creative Commons Attribution International License (CC BY).

http://creativecommons.org/licenses/by/4.0/

c) (i) Open Access

\begin{abstract}
Several studies are conducted to improve nutritional enrichment of ice cream. The aim of the present study was to produce healthy ice cream by partial replacement of fat with whey protein (WP), dietary fibers (oat (OT) and wheat germs (WG)) and modified starch (MS). Reduced fat ice cream ( $8 \%$ fat) was prepared as control. Healthy reduced fat ice cream was prepared by replacing $1 \%$ and $2 \%$ of fat with WP, OT, WG and MS. The fat replacement with OT and WG increased the fiber content of ice cream. In addition, ice cream from all treatments characterized by a significant great free radical scavenging activity when compared with control, especially when fat was replaced with WG, WP and OT, respectively. The sensory evaluation of ice cream revealed an enhancement of flavor when fat was replaced with 1\% WP and OT and $2 \%$ WP (P $<0.05$ vs. control). The modified starch treatments (1\% and $2 \%)$ showed the highest viscosity followed by OT (2\%) treatment $(P<\mathbf{0 . 0 5})$. In conclusion, these results showed that dietary fibers (OT \& WG), WP and MS could be used to replace fat in ice cream and to give a healthy reduced fat ice cream with high fiber content and with high antioxidant activity.
\end{abstract}

\section{Keywords}

Reduced Fat Ice Cream, Antioxidant Activity, Oat, Wheat Germ, Whey Protein

How to cite this paper: Salem, S.A., Hamad, E.M. and Ashoush, I.S. (2016) Effect of Partial Fat Replacement by Whey Protein, Oat, Wheat Germ and Modified Starch on Sensory Properties, Viscosity and Antioxidant Activity of Reduced Fat Ice Cream. Food and Nutrition Sciences, 7, 397-404. http://dx.doi.org/10.4236/fns.2016.76041 


\section{Introduction}

Ice cream is a frozen dairy products composed of milk, sugar, stabilizer, emulsifier and flavoring. Ice cream is considered as a complex colloidal system with a unique structure depended on air bubbles and other structural compounds [1]. At present, there is an increasing concern about the effect of diet on health and quality of life. Consumers are interested in reduced fat products that are less associated with the risk of chronic diseases such as obesity and coronary heart diseases [2]. The Food and Drug Administration has approved the use of labeling names of reduced-fat, low-fat and non-fat ice creams for such products that containing less than $10 \%$ milk fat [3]. Due to the fact that fat is an important determinant for texture and quality of ice cream, reduced fat ice cream has a body and textural problems. Therefore, the dairy manufacturers use some fat replacers to improve quality of reduced fat ice cream [2] [4]. The fat in ice cream can be partially replaced with low energy nutrients such as proteins (i.e. whey proteins) or carbohydrates (i.e. modified starch) [5]. In addition, different dietary fibers are used as fat replacers in reduced fat ice cream [6].

Dietary fibers include a group of heterogeneous food constituents such as celluloses, hemicelluloses, lignins, pectins, and seaweed. Dietary fibers can be found in different food sources such as oat, wheat, inulin and apple. Several studies show the physiological and nutritional aspects of dietary fibers. Therefore, different studies try to incorporate dietary fibers in several food products to increase their health benefits [7]. The physiological effects of food products supplemented with dietary fibers include the improvement of gastrointestinal health, protection against colon cancer, reducing blood total and low-density lipoprotein cholesterol, lower blood glucose after meal, and immunostimulants [8]. The use of dietary fibers shows a significant improvement in melting quality of ice cream with a minimal effect on viscosity, overrun and texture [6] [9]. In another study, both oat and wheat fibers improve viscosity development due to water-binding capacity [10].

Whey and whey products have been used successfully in ice cream and other frozen dairy desserts for years. Whey proteins are a good source of essential amino acids and bioactive peptides. The incorporation of WP in ice cream shows an improvement in overrun, creaminess, smoothness and flavor [11] [12]. Recently, WP improves sensory properties besides improving the protein content of reduced fat ice cream [2] [13].

Starch is a common plant polysaccharide carbohydrate, which consists of a very big number of glucose units. In order to enhance functional properties of starch, several studies have used different chemicals or enzymes to modify starch [14]. The resulted modified starch shows enhanced properties such as higher water holding capacity and improved thickening that enable modified starch to be used as a food additives and fat replacers [15]. Modified starch is used previously for production of low fat butter spread/margarine and low fat milk type products [16] and low fat ice cream [4].

The objective of the present study was to determine the effects of partial replacement of fat with dietary fibers (oat and wheat germ), whey proteins and modified starch on viscosity, antioxidant activity and sensory evaluation of reduced fat ice cream.

\section{Materials and Methods}

\subsection{Materials}

The ingredients of ice cream mix included pasteurized cow's milk and cream which obtained from El-Maray company, while skim milk powder, whey protein powder, modified starch, wheat germ, oat, granulated can sugar, glucose, gelatin and emulsifiers (Egg yolk) were obtained from the local markets in Buridah, Qassim.

\subsection{Ice Cream Mix Preparation}

The control reduced fat ice cream mix was prepared [3]. Other eight Ice cream mixes were calculated and prepared from the above-mentioned ingredients and their compositions are presented in Table 1. All mixes were heated at $75^{\circ} \mathrm{C}$ for $10 \mathrm{~min}$, then rapidly cooled to $4^{\circ} \mathrm{C}$ then egg yolk was added and stored at the same temperature overnight for ageing. The aged ice cream mixes were frozen in an experimental ice cream batch freezer (Automatic ice cream maker, Delonghi, II Gelatia, Italy). The ice cream were put into PVC cups (ca $200 \mathrm{ml}$ ) containers and hardened at $-18^{\circ} \mathrm{C}$ for $24 \mathrm{~h}$ before analyses. Three replicates were carried out for each treatment.

\subsection{Methods of Analysis}

\subsubsection{Physicochemical Analysis, and Overrun for Ice Cream Mixes}

Ice cream samples were analyzed for their crude fiber according to the methods described in AOAC [17]. For 
Table 1. Composition of ice cream mixes.

\begin{tabular}{|c|c|c|c|c|c|c|c|c|c|}
\hline \multirow{3}{*}{ Ingredients (\%) } & \multirow{3}{*}{ Control } & \multicolumn{8}{|c|}{ Treatments } \\
\hline & & \multicolumn{4}{|c|}{$1 \%$ Fat Replacement } & \multicolumn{4}{|c|}{$2 \%$ Fat Replacement } \\
\hline & & MS1 & WP1 & WG1 & OT1 & MS2 & WP2 & WG2 & OT2 \\
\hline Fat & 8 & 7 & 7 & 7 & 7 & 6 & 6 & 6 & 6 \\
\hline MSNF & 11 & 11 & 11 & 11 & 11 & 11 & 11 & 11 & 11 \\
\hline Sugar ( $66 \%$ sucrose $+33 \%$ glucose) & 16 & 16 & 16 & 16 & 16 & 16 & 16 & 16 & 16 \\
\hline Stabilizers (Gelatin) + Emulsifier (Egg yolk) & 0.5 & 0.5 & 0.5 & 0.5 & 0.5 & 0.5 & 0.5 & 0.5 & 0.5 \\
\hline MS & - & 1 & - & - & - & 2 & - & - & - \\
\hline WP & - & - & 1 & - & - & - & 2 & - & - \\
\hline WG & - & - & - & 1 & - & - & - & 2 & - \\
\hline OT & - & - & - & - & 1 & - & - & - & 2 \\
\hline Total solids & 35.5 & 35.5 & 35.5 & 35.5 & 35.5 & 35.5 & 35.5 & 35.5 & 35.5 \\
\hline
\end{tabular}

MSNF: milk solids not fat; MS: modified starch; WP: whey proteins; WG: wheat germ; OT: oat.

the $\mathrm{pH}$ measurement, about $100 \mathrm{~g}$ ice cream samples were melted at $5^{\circ} \mathrm{C}$ then the $\mathrm{pH}$ was measured using a pH meter (model Jenway 3310). The overrun, was measured as described by Arbuckle [18]. To determine the melting resistance (Meltdown), the blocks of frozen ice cream weighting $200 \mathrm{~g}$ at $-18^{\circ} \mathrm{C}$ allowed melting at $22^{\circ} \mathrm{C} \pm$ $2^{\circ} \mathrm{C}$ for $45 \mathrm{~min}$. The melting resistance was calculated according to Mathur and Srinivasan [19].

\subsubsection{Antioxidant Activity (DPPH Free Radicals Scavenge) Assay}

The ability of the ice cream mixes to scavenge DPPH free radicals was determined by the method described by Blois [20]. Each sample $(30 \mu \mathrm{l})$ was mixed with $1.0 \mathrm{ml}$ of DPPH $(0.1 \mathrm{mM}$ in methanol). The reaction mixture was allowed to react for $20 \mathrm{~min}$ at room temperature. The remaining DPPH free radical was determined by absorbance measurement at $517 \mathrm{~nm}$ against methanol blanks. The percentage scavenging effect was calculated from the reduction of absorbance against control (DPPH radical solution in methanol without sample) according to the following equation by Blois [20]:

Scavenging activity $\%=[($ Absorbance of control - Absorbance of sample $) /$ Absorbance of control $] \times 100$

\subsubsection{Apparent Viscosity}

Measurements of apparent viscosity of aged ice-cream mixes were carried out according to Metwally [21] with some modifications. Brookfield Programmable Rheometer (Model RVDV-III Ultra; Brookfield Engineering Laboratories, Stoughtm, MA, USA) was used for viscosity measurements. All mixes were tempered for 5 min at $20^{\circ} \mathrm{C} \pm 1^{\circ} \mathrm{C}$ in a concentric cylinder with RV spindle number 3 at $40 \mathrm{rpm}$. Rheocalc software (ver. 2.5, Brookfield Engineering Laboratories, Inc.) was used to collect the values of apparent viscosity.

\subsubsection{Color Parameter Evaluation}

The color of ice cream samples was measured using a colorimeter (Model Hunter Lab color Flex). The L, a, and b values were recorded, with $L$ denoting lightness on a 0 - 100 scale from black to white; a, red (+) or green (-); and b, yellow $(+)$ or blue $(-)$ as described by Francis [22].

\subsubsection{Sensory Evaluation}

The sensory evaluation of the ice cream was judged by 10 experienced panelists from Department of Food Science and Human Nutrition, College of Agric. and Vet. Med., Qassim Univ., KSA using a score test. The ice cream samples were assessed for flavor (40), texture (30), color (15) and melting (15) using a report sheet according to Watts et al. [23].

\subsubsection{Statistical Analyses}

Data were analyzed by one-way analysis of variance (ANOVA), followed by assessment of differences by Tu- 
key's post-hoc test. All statistical calculations were performed using SPSS version 16.0. Results were considered statistically significant at $\mathrm{P}>0.05$.

\section{Results and Discussion}

\subsection{Physicochemical Properties, Antioxidant Activity and Overrun}

Data presented in Table 2 showed the effect of different replacements of fat (1\% \& 2\%) with modified starch (MS), whey protein (WP), oat (OT) and wheat germ (WG) on physicochemical properties, antioxidant activity and overrun of reduced fat ice cream. As can be noticed, there was not significant different between all treatments in $\mathrm{pH}$ value. The addition of WP showed a slight reduction in the $\mathrm{pH}$ value. In other study, WP showed a significant increasing in the acidity of ice cream [13]. In addition, addition of MS showed a tendency to increase value of $\mathrm{pH}$. Generally, MS can be prepared by using acid, alkaline and enzymes [15]. Therefore, it could be the nature of composition of MS that showed a tendency to increase the $\mathrm{pH}$ value of the resultant ice cream.

From Table 2 also, it can be noticed that the overrun of all ice cream treatments were decreased significantly by addition of MS, WP, OT and WG when compared with control. Replacement with dietary fibers did not show any tendency of improvement for overrun. Dietary fibers also showed an increase in the melting of ice cream. In similar study, the use of fibers improved melting properties, but failed to increase overrun of ice cream ([9] \& [6]). Addition of WP showed no effect on the overrun, but increased meltdown significantly when fat was replaced by $2 \%$. This is not in agreement with other study that observed an increased melting resistance when WP added [13]. The difference between the results of the present study and the previous one could be due to the difference in the quantity of WP which was larger in the previous report than that used in the present study.

The addition of MS, WP, OT and WG resulted in a significant increasing in the crude fibers of ice cream compared to the control (Table 2). The higher fiber content was accounted for the ice cream fortified with oat and wheat germ (1\% and $2 \%$ ). Besides, addition of MS and WP in ice cream showed a moderate amount of crude fibers.

Ice cream from all treatments characterized by significantly greater free radical scavenging activity compared to the control, especially when wheat germ, whey protein and oat were added to ice cream, respectively. These findings are in harmony with those obtained by Ford-Martin [24].

\subsection{Sensory Evaluation of Ice Cream Mixes}

The sensory scores of the ice cream samples are given in Table 3. An improvement in the flavor of ice cream was observed when fat was replaced with 1\% WP or OT and 2\% WP. Also, there was no significant effect of all treatments on the color of ice cream except replacement of fat with $2 \%$ WG and OT which showed a significant

Table 2. Effect of partial fat replacement by whey proteins (WP), wheat germ (WG), oat (OT) and modified starch (MS) on physicochemical properties of reduced fat ice cream.

\begin{tabular}{|c|c|c|c|c|c|}
\hline Treatments & pH value & Overrun (\%) & Meltdown (ml) & Crude fibers (\%) & DPPH (\%) \\
\hline Control & $6.77 \pm 0.06^{\mathrm{c}}$ & $75.00 \pm 2.00^{\mathrm{a}}$ & $32.00 \pm 2.50^{d}$ & $0.062 \pm 0.02^{\mathrm{e}}$ & $20.08 \pm 4.44^{\mathrm{d}}$ \\
\hline \multicolumn{6}{|c|}{$1 \%$ Fat Replacement } \\
\hline MS1 & $6.82 \pm 0.03^{\mathrm{bc}}$ & $36.00 \pm 1.00^{\text {de }}$ & $48.00 \pm 2.80^{\mathrm{abc}}$ & $0.137 \pm 0.04^{\mathrm{d}}$ & $33.30 \pm 6.76^{c}$ \\
\hline WP1 & $6.83 \pm 0.04^{\mathrm{bc}}$ & $40.00 \pm 2.00^{\mathrm{d}}$ & $30.00 \pm 3.60^{\mathrm{d}}$ & $0.085 \pm 0.01^{\mathrm{c}}$ & $70.75 \pm 2.10^{\mathrm{ab}}$ \\
\hline WG1 & $6.78 \pm 0.04^{\mathrm{c}}$ & $45.00 \pm 1.00^{c}$ & $43.00 \pm 2.20^{c}$ & $0.229 \pm 0.05^{\mathrm{b}}$ & $78.86 \pm 4.44^{\mathrm{a}}$ \\
\hline OT1 & $6.82 \pm 0.03^{\mathrm{bc}}$ & $50.50 \pm 0.80^{\mathrm{b}}$ & $36.00 \pm 2.40^{\mathrm{d}}$ & $0.268 \pm 0.02^{\mathrm{a}}$ & $64.09 \pm 2.81^{\mathrm{b}}$ \\
\hline \multicolumn{6}{|c|}{ 2\% Fat Replacement } \\
\hline MS2 & $6.91 \pm 0.03^{\mathrm{ab}}$ & $38.80 \pm 0.40^{\text {de }}$ & $55.00 \pm 2.60^{\mathrm{a}}$ & $0.183 \pm 0.03^{\mathrm{c}}$ & $42.95 \pm 2.90^{c}$ \\
\hline WP2 & $6.76 \pm 0.02^{\mathrm{c}}$ & $47.60 \pm 1.30^{c}$ & $51.00 \pm 3.30^{\mathrm{ab}}$ & $0.097 \pm 0.02^{\mathrm{b}}$ & $71.33 \pm 4.05^{\mathrm{ab}}$ \\
\hline WG2 & $6.86 \pm 0.08^{\mathrm{bc}}$ & $35.40 \pm 1.60^{\mathrm{e}}$ & $48.00 \pm 1.60^{\mathrm{abc}}$ & $0.237 \pm 0.06^{\mathrm{b}}$ & $80.12 \pm 2.29^{a}$ \\
\hline OT2 & $6.82 \pm 0.04^{\mathrm{bc}}$ & $45.80 \pm 1.10^{\mathrm{c}}$ & $44.00 \pm 1.20^{\mathrm{bc}}$ & $0.298 \pm 0.07^{\mathrm{a}}$ & $72.88 \pm 1.90^{\mathrm{ab}}$ \\
\hline
\end{tabular}

Data are the mean \pm SE $(n=3)$, Mean values in the same column bearing the same superscript do not differ significantly $(\mathrm{P}>0.05)$. 
Table 3. Effect of partial fat replacement by whey proteins (WP), wheat germ (WG), oat (OT) and modified starch (MS) on sensory evaluation of reduced fat ice cream.

\begin{tabular}{|c|c|c|c|c|}
\hline Treatments & Flavor (40) & Texture (30) & Color (15) & Melting (15) \\
\hline Control & $27.44 \pm 5.98^{b}$ & $27.67 \pm 3.04^{\mathrm{a}}$ & $14.01 \pm 2.13^{\mathrm{a}}$ & $11.49 \pm 2.82^{\mathrm{a}}$ \\
\hline \multicolumn{5}{|c|}{ 1\% Fat Replacement } \\
\hline MS1 & $32.22 \pm 5.17^{\mathrm{ab}}$ & $23.44 \pm 3.61^{\mathrm{a}}$ & $14.66 \pm 1.32^{\mathrm{a}}$ & $9.33 \pm 2.34^{\mathrm{a}}$ \\
\hline WP1 & $35.33 \pm 2.40^{\mathrm{a}}$ & $26.67 \pm 3.24^{\mathrm{a}}$ & $12.84 \pm 2.01^{\mathrm{ab}}$ & $10.83 \pm 2.58^{\mathrm{a}}$ \\
\hline WG1 & $34.22 \pm 5.36^{\mathrm{ab}}$ & $24.22 \pm 4.76^{\mathrm{a}}$ & $12.66 \pm 3.60^{\mathrm{abc}}$ & $11.67 \pm 2.34^{\mathrm{a}}$ \\
\hline OT1 & $35.44 \pm 3.50^{\mathrm{a}}$ & $26.78 \pm 4.27^{\mathrm{a}}$ & $12.33 \pm 2.79^{\mathrm{abc}}$ & $11.67 \pm 2.34^{\mathrm{a}}$ \\
\hline \multicolumn{5}{|c|}{ 2\% Fat Replacement } \\
\hline MS2 & $33.11 \pm 5.18^{\mathrm{ab}}$ & $26.00 \pm 4.12^{\mathrm{a}}$ & $14.01 \pm 1.50^{\mathrm{a}}$ & $11.34 \pm 3.27^{\mathrm{a}}$ \\
\hline WP2 & $35.11 \pm 3.76^{\mathrm{a}}$ & $25.00 \pm 5.96^{\mathrm{a}}$ & $12.00 \pm 2.13^{\mathrm{abc}}$ & $11.67 \pm 3.15^{\mathrm{a}}$ \\
\hline WG2 & $30.44 \pm 3.64^{\mathrm{ab}}$ & $22.56 \pm 3.17^{\mathrm{a}}$ & $9.33 \pm 2.34^{\mathrm{c}}$ & $11.01 \pm 2.13^{\mathrm{a}}$ \\
\hline OT2 & $29.89 \pm 5.18^{\mathrm{ab}}$ & $25.00 \pm 3.87^{\mathrm{a}}$ & $10.32 \pm 1.59^{\mathrm{bc}}$ & $9.66 \pm 2.49^{\mathrm{a}}$ \\
\hline
\end{tabular}

Data are the mean $\pm S E, n=10$, Mean values in the same column bearing the same superscript do not differ significantly (P $>0.05$ ).

lowered score for color. There was no significant effect of all treatments on texture and melting of the resultant ice cream. In line with other studies, the present results showed a good overall acceptability of the ice cream fortified with MS, WP, OT and WG [6] [13].

\subsection{Viscosity of Ice Cream Mixes}

Figure 1 illustrated the mean values of apparent viscosity (cP) for mixtures of ice cream contain MS, WP, OT and WG. As it can be noticed, replacement of fat (1\% or $2 \%)$ with MS showed the highest viscosity followed by OT $(\mathrm{P}<0.05)$. Both WP and WG showed similar viscosity values when they added with the same ratio. Viscosity of WP1 and WG1 treatments showed viscosity values similar to that of the control. However, these results indicated that the viscosity of the resultant ice-cream samples was greatly increased when modified starch (1\% or $2 \%$ ) and oat (2\%) was added. These high values of viscosity could be due to the ability of starch and oat to improve network of ice cream, which constrains the serum areas and, thus, leads to increased viscosity.

Previously, addition of oat and wheat fibers to ice cream was characterized by a significant improvement of viscosity characteristic of the resultant ice cream. This improvement in viscosity could be likely induced by the presence of insoluble materials and high water retention ability of oat and wheat fibers ([10]). Similar to our results, Ruger et al. [25] found that addition of $1 \%$ whey proteins did not affect viscosity in ice-cream mix. In addition, Tomer and Kumar [26] found that the viscosity of ice cream was higher in the treatment containing 2.26\% milk protein concentrate than that containing $1.42 \%$ milk protein concentrate.

\subsection{Color Parameter of Ice Cream Mixes}

Figure 2 illustrated the average values for L, a, b of color measurements by Hunter Colorimeter for ice cream treatments. The "L" values are determining the black (0) to white $(100)$ color. The range of "L" value for all treatments was from 83.3 to 88.8. All ice-cream treatment were quiet similar in "L" value to that of control. The "a" value is an indicator of red (positive values) to green (negative values) color. As shown, all "a" values are negative which indicate that all treatment showed more green color than red color. The addition of whey proteins resulted in a slight reduction in "a" value (1.51 and 0.77 for WP1 and WP2, respectively) compared to control (2.52). In addition, the results of "b" value are comparing yellow (positive values) to blue (negative values) colors. It is clear that all of the additives that used in the present study increased yellowish color of the resultant ice cream. It can also be noticed that WG2, WP1 and WP2 treatments were showing the highest "b" values (17.07, 15.16 and 19.80, respectively) among all other treatments and control. The obtained results are in line with those found by Akalin et al. [2] who found no effect of whey protein addition on the analytical measures of color. Also, it was found earlier that the increasing of addition of wheat germ was accompanied by an 


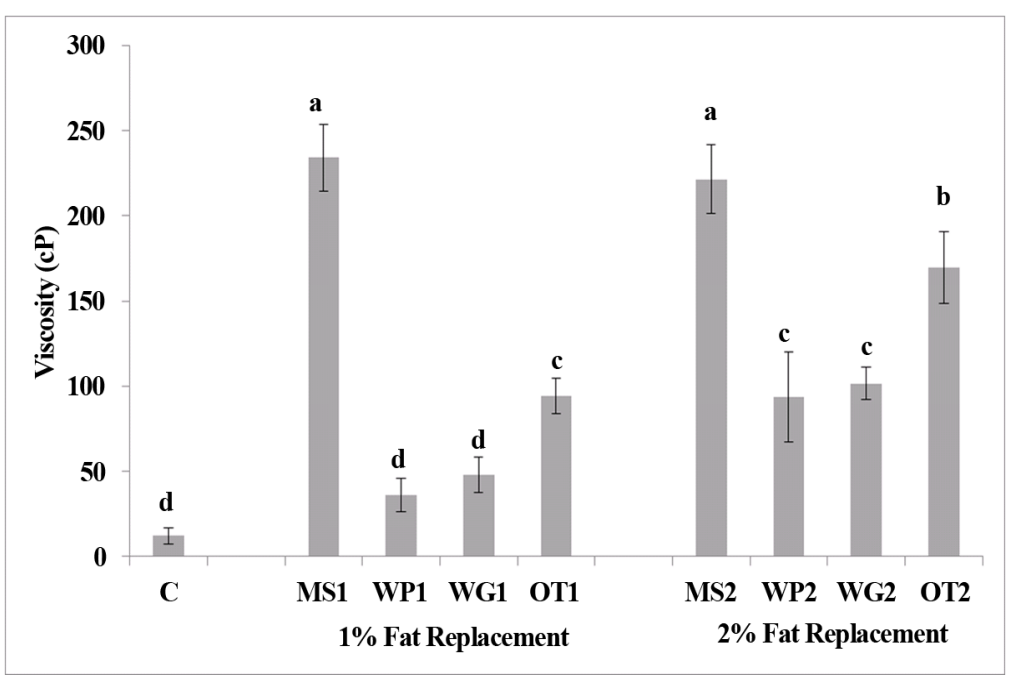

Figure 1. Effect of partial fat replacement by whey proteins (WP), wheat germ (WG), oat (OT) and modified starch (MS) on apparent viscosity of reduced fat ice cream. Mean values bearing the same superscript do not differ significantly $(\mathrm{P}>0.05)$.

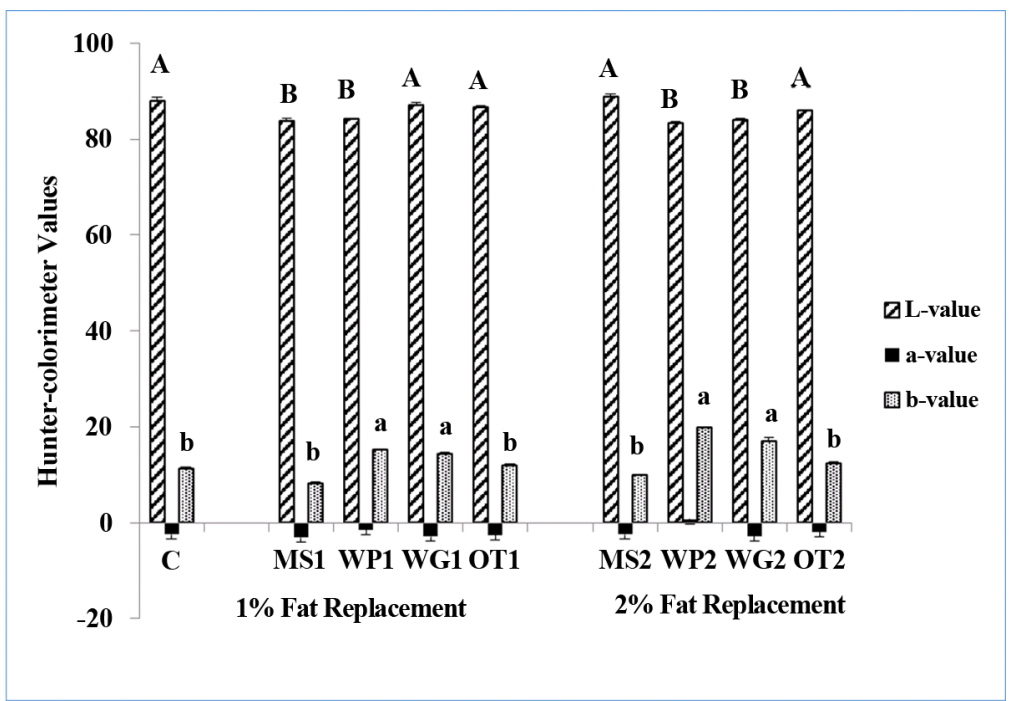

Figure 2. Effect of partial fat replacement by whey proteins (WP), wheat germ (WG), oat (OT) and modified starch (MS) on color values of reduced fat ice cream. Mean values bearing the same superscript do not differ significantly (P > 0.05). Capital letters refer to L-value. Small letters refer to b-value.

increase in the yellowness of a syrup blend [27].

\section{Conclusion}

Based on the above results, it could be concluded that reduced fat ice cream could be prepared by $1 \%$ and $2 \%$ fat replacement with MS, WP, OT and WG. These additives showed an improvement of sensory properties as well as increasing antioxidant activity and fiber content of the final reduced ice cream product. Replacement of fat with MS improved viscosity and overrun of the resulted ice cream. Addition of WP improved flavor of the final ice cream. While addition of OT increased fiber content, the addition of WG showed the highest antioxidant activity of the resulted ice cream. Therefore, the results of the present study confirmed the possibility of producing healthy ice cream with lower fat content and with higher dietary fibers and antioxidant activity. 


\section{References}

[1] Clarke, C. (2004) The Science of Ice Cream. The Royal Society of Chemistry, Cambridge, 208.

[2] Akalın, A.S., Karagözlü, C. and Ünal, G. (2008) Rheological Properties of Reduced-Fat and Low-Fat Ice Cream Containing Whey Protein Isolate and Inulin. European Food Research and Technology, 227, 889-895. http://dx.doi.org/10.1007/s00217-007-0800-z

[3] Marshall, R.T. and Arbuckle, W.S. (1996) Ice Cream. 5th Edition, Chapman \& Hall, New York. http://dx.doi.org/10.1007/978-1-4613-0477-7

[4] Aime, D.B., Arntfield, S.D., Malcolmson, L.J. and Ryland, D. (2001) Textural Analysis of Fat Reduced Vanilla Ice Cream Products. Food Research International, 34, 237-246. http://dx.doi.org/10.1016/S0963-9969(00)00160-5

[5] Guven, M., Yas-ar, K., Karaca, O.B. and Hayaloglu, A.A. (2005) The Effect of Inulin as a Fat Replacer on the Quality of Set-Type Low-Low Yogurt Manufacture. International Journal of Dairy Technology, 58, 180-184. http://dx.doi.org/10.1111/j.1471-0307.2005.00210.x

[6] Tiwari, A., Sharma, H.K., Kumar, N. and Kaur, M. (2015) The Effect of Inulin as a Fat Replacer on the Quality of Low-Fat Ice Cream. International Journal of Dairy Technology, 68, 374-380. http://dx.doi.org/10.1111/1471-0307.12176

[7] Gelroth, J. and Ranhotra, G.S. (2001) Food Uses of Fiber. In: Sungsoo Cho, S. and Dreher, M.S., Eds., Handbook of Dietary Fiber, Taylor and Francis, New York, 345-452. http://dx.doi.org/10.1201/9780203904220.pt4

[8] Tungland, B.C. and Meyer, D. (2002) Non-Digestible Oligo and Polysaccharides (Dietary Fibre): Their Physiology and Role in Human Health and Food. Comprehensive Reviews in Food Science and Food Safety, 1, 73-92. http://dx.doi.org/10.1111/j.1541-4337.2002.tb00009.x

[9] Dervisoglu, M. and Yazici, F. (2006) The Effect of Citrus Fiber on the Physical, Chemical and Sensory Properties of Ice Cream. Food Science and Technology International, 12, 159-164. http://dx.doi.org/10.1177/1082013206064005

[10] Soukoulis, C., Lebesi, D. and Tzia, C. (2009) Enrichment of Ice Cream with Dietary Fibre: Effects on Rheological Properties, Ice Crystallisation and Glass Transition Phenomena. Food Chemistry, 115, 665-671. http://dx.doi.org/10.1016/j.foodchem.2008.12.070

[11] Thompson, L.V., Reniers, D.J., Baer, L.M. and Siu, M. (1983) Succinated WPC in Ice Cream and Instant Pudding. Journal of Dairy Science, 66, 1630-1637. http://dx.doi.org/10.3168/jds.S0022-0302(83)81985-7

[12] Vulnik, N. (1995) The Use of Whey Powders in Ice Cream Manufacture. Confectionery Production, 6, 154-155.

[13] Pandiyan, C., Kumaresan, G., Annal, V.R. and Rajarajan, G. (2010) Incorporation of Whey Protein Concentrates in Ice Cream. International Journal of Chemical Sciences, 8, s563-s567.

[14] CODEX ALIMENTARIUS (2001) Modified Starches. Published in FNP 52 Add 9. http://www.fao.org/ag/agn/jecfa-additives/specs/Monograph1/Additive-287.pdf

[15] Abbas, K.A., Khalil, S.K. and Hussin, A.S.M. (2010) Modified Starches and Their Usages in Selected Food Products: A Review Study. Journal of Agricultural Science, 2, 90-100. http://dx.doi.org/10.5539/jas.v2n2p90

[16] Sajilata, M.G. and Singhal, R.S. (2005) Specialty Starches for Snack Foods. Carbohydrate Polymers, 59, 131-151. http://dx.doi.org/10.1016/j.carbpol.2004.08.012

[17] AOAC (2007) Official Methods of Analysis. 18th Edition, Association of Official Analytical chemists, Gaithersburg.

[18] Arbuckle, W.S. (1986) Ice Cream. 3rd Edition. AVI Publishing Co., Westport. http://dx.doi.org/10.1007/978-1-4615-7222-0

[19] Mathur, B.N. and Srinivasan, M. (1979) Isolation and Utilization of Proteins from Whey Systems of Buffalo Milk on Pilot Scale. II-Utilization of Whey Protein Isolates in Formulated Dairy Products. Journal of Food Science and Technology, 16, 47.

[20] Blois, M.S. (1958) Antioxidant Determinations by the Use of a Stable Free Radical. Nature, 181, 1199-1200. http://dx.doi.org/10.1038/1811199a0

[21] Metwally, A.M.M.E. (2007) Effect of Enzymatic Cross-Linking of Milk Proteins on Properties of Ice Cream with Different Composition. International Journal of Food Science \& Technology, 42, 939-947. http://dx.doi.org/10.1111/j.1365-2621.2006.01314.x

[22] Francis, F.J. (1983) Colorimetry of Foods. In: Peleg, M. and Bagly, E.B., Eds., Physical Properties of Foods, The AVI Publishing Company Inc., Westport, 105-123.

[23] Watts, B.M., Ylimaki, G.L., Jeffery, L.E. and Elias, L.G. (1989) Basic Sensory Methods for Food Evaluation. International Development Research Center, Ottawa, 60-63.

[24] Ford-Martin, P. (2005) Wheat Germ. Gale Encyclopedia of Alternative Medicine. 
http://www.healthline.com/galecontentlwheat-germ

[25] Ruger, P.R., Baer, R.J. and Kasperson, K.M. (2002) Effect of Double Homogenization and Whey Protein Concentrate on the Texture of Ice Cream. Journal of Dairy Science, 85, 1684-1692. http://dx.doi.org/10.3168/jds.S0022-0302(02)74241-0

[26] Tomer, V. and Kumar, A. (2013) Development of High Protein Ice-Cream Using Milk Protein Concentrate. IOSR Journal of Environmental Science, Toxicology and Food Technology (IOSR-JESTFT), 6, 71-74.

[27] Ammar, A.S.M. (2012) Effect of Wheat Germ Addition on Physicochemical and Antioxidant Properties of Date Syrup. American Journal of Food Technology, 7, 479-486. http://dx.doi.org/10.3923/ajft.2012.479.486 